\title{
JAJANAN SEHAT DAN KAYA KALSIUM UNTUK KELUARGA: SUBTITUSI TEPUNG BANDENG PRESTO SEBAGAI BAHAN KASTANGEL
}

\author{
Meddiati Fajri Putri ${ }^{1 *}$, Cinta Amalia Kasih ${ }^{1}$ \\ ${ }^{1}$ Program Studi Pendidikan Kesejahteraan Keluarga, Fakultas Teknik, Universitas Negeri Semarang, \\ Semarang 50221, Indonesia \\ *) E-mail: media@mail.unnes.ac.id
}

\begin{abstract}
Abstrak
Ikan bandeng merupakan budidaya perikanan air payau di Indonesia. Ikan bandeng dapat diolah menjadi beraneka makanan olahan, seperti bandeng duri lunak, pepes bandeng, otak-otak bandeng, dan produk hasil olahan lainnya. Kandungan nutrisi bandeng duri lunak relatif tinggi untuk mencukupi kebutuhan gizi masyarakat dengan harga relatif terjangkau. Kandungan gizi pada tepung bandeng presto tersebut dijadikan subtitusi dalam pembuatan kastangel. Tujuan dari penelitian ini adalah untuk mengetahui perbedaan kualitas kastangel subtitusi tepung bandeng presto, untuk mengetahui tingkat kesukaan masyarakat dan untuk mengetahui kandungan kalsium dan protein dengan prosentase $0 \%$, $10 \%, 20 \%$, dan $30 \%$ ditinjau dari aspek warna, aroma, aroma bandeng presto, dan tekstur.Tujuan penelitian ini adalah untuk mengetahui kualitas kastangel hasil eksperimen ditinjau dari kualitas inderawi, tingkat kesukaan masyarakat serta kandungan protein dan kalsium. Metode penelitian yang digunakan analisis varian (Anava) one way, dan dilanjutkan uji Tukey apabila ada perbedaan kualitas inderawi pada produk, uji kesukaan menggunakan deskriptif prosentase untuk mengetahui tingkat kesukaan masyarakat, uji Laboratorium untuk mengetahui kandungan gizi protein dan kalsium. Hasil penilitian menunjukan bahwa terdapat perbedaan kualitas inderawi pada indikator aroma bandeng presto dan tekstur dengan nilai signifikan kurang dari 0,05. hasil uji kesukaan Sampel yang disukai masyarakat $0 \%, 10 \%$ dan $20 \%$ dengan prosentase $(55,75 \%, 55,25 \%$, dan $52,9 \%)$. Hasil uji laboratorium kandungan kalsium dan protein Sampel kastangel subtitusi tepung bandeng presto $30 \%$ (13,83\%,:5,42\%), 20\% (11,36\%:3,66\%), 10\% (9,60\%: 2,33\%), 0\% (8,26:0,49\%).
\end{abstract}

Kata Kunci : Kastangel, Tinggi Kalsium, Tepung bandeng presto

\section{Healthy and Calcium Rich Snacks for Family: Subtitution Flour Bandeng Presto as Composition of Kastangel}

\begin{abstract}
Milkfish is brackish water aquaculture in Indonesia. Milkfish can be processed into a variety of processed foods, such as soft thorns, milkfish, milk brains, and other processed products. The nutrient content of soft thorns is relatively high to meet the nutritional needs of the people at relatively affordable prices. The nutritional content of presto milkfish flour is used as a substitution in the making of kastangel. The purpose of this study was to determine differences in the quality of presto milkfish substitution castor, to determine the level of community preference and to determine the content of calcium and protein with a percentage of $0 \%, 10 \%, 20 \%$, and $30 \%$ in terms of aspects of color, aroma, milkfish aroma presto, and texture. The purpose of this research is to find out the quality of the castellated experimental results in terms of sensory quality, people's favorite level and protein and calcium content. The research method used is one way analysis of variance (ANAVA), and Tukey test is continued if there is a difference in the sensory quality of the product, the preference test uses descriptive percentages to determine the level of community preference, Laboratory tests to determine the nutritional content of protein and calcium. The results of the study indicate that there are differences in sensory quality on the presto milkfish aroma and texture indicators with a significant value less than 0.05 . Preferred test results The samples favored by the community are $0 \%, 10 \%$ and $20 \%$ with percentages $(55.75 \%, 55.25 \%$ and $52.9 \%)$. Laboratory test results of calcium and protein content Samples of castor substitution presto milkfish flour 30\% (13.83\%:5.42\%), $20 \%$ (11.36\%:3.66\%), 10\% (9.60\%:2,33\%), 0\% (8.26:0.49\%).
\end{abstract}

Keywords: bandeng presto flour, high calcium, kastangel 


\section{PENDAHULUAN}

Ikan bandeng merupakan budidaya perikanan air payau di Indonesia. Ikan bandeng dapat diolah menjadi beraneka makanan olahan, seperti bandeng duri lunak, pepes bandeng, otak-otak bandeng, dan produk hasil olahan lainnya (Wijayanto dan Widowati, 2012). Produksi ikan bandeng presto terus mengalami peningkatan setiap tahunnya. Berdasarkan data Badan Pusat Statistik Kota Semarang, produksi ikan bandeng presto pada bulan januari tahun 2019 mencapai 2.466.913 ton. Menurut Kurniasih, Sumardianto, Swastawati, dan Rianingsih (2017), setiap $100 \mathrm{~g}$ ikan bandeng presto mengandung 202,6 kkal energi, 27,10\% protein, 9,98\% lemak, 0,22\% kalsium, dan 58,93\% kadar air. Kandungan nutrisi pada ikan bandeng duri lunak juga relatif tinggi untuk mencukupi kebutuhan gizi masyarakat ditambah dengan harga relatif terjangkau (Wijayanto \& Widowati, 2012). Pada dasarnya ikan dapat dikonsumsi sebagai lauk pauk akan tetapi ikan juga dapat dimanfaatkan menjadi verifikasi olahan ikan bandeng presto lainnya. Perlakuan yang diberikan pada ikan dapat diaplikasikan pada berbagai macam produk pangan.

Ikan bandeng presto juga dapat diolah menjadi tepung. Tepung ini dapat digunakan sebagai bahan untuk membuat kue. Salah satu contohnya adalah kastangel. Kastengel adalah adonan yang mengandung keju edam, sehingga asin, berwarna kuning keemasan, dan halus (Anggraeni, Handayani, \& Palupi, 2017). Cookies adalah jenis biskuit yang berkadar lemak tinggi, renyah,dan bila dipatahkan penampang potongannya bertekstur kurang padat (Faridah, Pada, Yulastri, \& Yusuf, 2008). Cookies adalah makanan ringan siap saji, nyaman dan murah yang dihasilkan dari adonan yang tidak enak yang diubah menjadi produk berpori ringan, mudah dicerna dan membangkitkan selera melalui aplikasi panas (Olapade \& Adeyemo, 2014). Kualitas cookies juga tergantung dari bahan yang digunakan. Pembuatan cookies akan berhasil sesuai dengan kriteria apabila bahan yang digunakan bermutu tinggi, proses pencampuran adonan dan metode pembuatanya benar, serta lama pembakaran dan temperaturnya tepat (Faridah, Pada, Yulastri, \& Yusuf, 2008). Kastangel adalah kue kering yang renyah, adonan mengandung keju, kue ini berbentuk panjang dan memiliki warna kuning keemasan. Produk kastangel saat ini telah mengalami variasi campuran bahan baku atau mengganti bahan dasar dengan bahan baru yang bertujuan untuk meningkatkan nilai gizi dan memberikan varian yang lebih beragam untuk memperkaya nilai gizi. Bahan dasar dalam pembuatan kastangel adalah tepung terigu yang diverisivikasi olahan tepung bandeng presto dari hasil eksperimen akan dapat dilihat kualitas kastangel dari aspek tekstur, warna, rasa, aroma dan nilai gizinya. Sehingga diharapkan tepung bandeng presto dapat digunakan sebagai bahan dasar alternatif pengganti tepung terigu dalam pembuatan kastangel. Cookies dapat diklasifikasikan sebagai makanan siap saji dan enak. Secara tradisional, proses pembuatan kue cukup sederhana dengan bahan dasar terdiri dari tepung, telur, dan gula. Secara umum, cookies dikenal sebagai makanan yang rata, keras, dan renyah (Norhidayah, Noorlaila, \& Izzati, 2014). Bahan-bahan yang digunakan dalam pembuatan cookies dibedakan menjadi bahan pengikat (binding material) dan bahan pelembut (tenderizing material). Bahan pengikat terdiri dari tepung, air, susu bubuk, putih telur, dan cocoa, sedangkan bahan pelembut terdiri atas gula, lemak atau minyak (shortening), bahan pengembang, dan kuning telur (Faridah, Pada, Yulastri, \& Yusuf, 2008).

Pada penelitian ini ikan bandeng presto dijadikan sebagai tepung kemudian hasil tepung diaplikasikan pada pembuatan Kastangel dengan cara subtitusi bandeng presto. Kastangel yang dimaksudkan disini adalah produk Cookies atau kue kering. Ikan bandeng merupakan budidaya perikanan air payau di Indonesia. Ikan bandeng dapat diolah menjadi beraneka makanan olahan, seperti bandeng duri lunak, pepes bandeng, otak-otak bandeng, dan produk hasil olahan lainnya (Wijayanto \& Widowati, 2012). Dari data badan pusat statistik kota semarang Produksi ikan bandeng presto pada bulan januari tahun 2019 mencapai

2.466.913 ton. Menurut Kurniasih, Sumardianto, Swastawati, dan Rianingsih (2017) mengatakan bahwa setiap $100 \mathrm{~g}$ bandeng presto mengandung 202,6 kkal energi, 27,10\% protein, 9,98\% lemak, 0,22 \% kalsium, dan 58,93\% kadar air. Hal itu menunjukkan bahwa 
kandungan nutrisi bandeng duri lunak relatif tinggi untuk mencukupi kebutuhan gizi masyarakat dengan harga relatif terjangkau (Wijayanto \& Widowati, 2012). Pada dasarnya ikan dapat dikonsumsi sebagai lauk pauk akan tetapi ikan juga dapat dimanfaatkan menjadi verifikasi olahan ikan bandeng presto lainnya. Perlakuan yang diberikan pada ikan dapat diaplikasikan pada berbagai macam produk pangan.

Kastengel adalah adonan mengandung keju edam, sehingga asin, berwarna kuning keemasan, dan halus (Anggraeni, Handayani, \& Palupi, 2017). Cookies adalah jenis biskuit yang berkadar lemak tinggi, renyah,dan bila dipatahkan penampang potongannya bertekstur kurang padat (Faridah, Pada, Yulastri, \& Yusuf, 2008). Cookies adalah makanan ringan siap saji, nyaman dan murah yang dihasilkan dari adonan yang tidak enak yang diubah menjadi produk berpori ringan, mudah dicerna dan membangkitkan selera melalui aplikasi panas (Olapade \& Adeyemo, 2014). Cookies adalah kue kering berasa manis atau gurih. Bertekstur renyah biasanya bentuknya kecil yang habis dalam 1 atau 2 kali gigitan. Pada umumnya terbuat dari bahan dasar tepung, lemak, dan telur dan diselesaikan dengan cara dioven. Cookies dikenal sebagai biskuit, cookie sangat ideal untuk ketersediaan nutrisi, kelezatan, kekompakan dan kenyamanan, mudah dimakan, memiliki tinggi nilai gizi, dan terjangkau (Santos, et al., 2018 ). Cookies merupakan produk pastry yang biasanya terbuat dari tepung terigu, telur, gula, susu, dan margarin dengan menggunakan teknik pengovenan. Cookies adalah produk pemanggangan dengan kandungan gula dan lemak yang tinggi relatif terhadap tepung dan sedikit air. Pada pembuatan cookies, lemak berfungsi untuk memberikan efek shortening dengan memperbaiki struktur fisik seperti volume pengembangan, tekstur, kelembutan, serta memberi flavour. Peningkatan mentega meningkatkan rasa ini dapat dijelaskan karena fakta bahwa mentega menambah kekayaan, kelezatan dan krim dari produk yang dipanggang seperti cookies yang sangat disukai oleh konsumen (Chakrabarti, Poonia, \& Chauhan, 2017). Kualitas cookies juga tergantung dari bahan yang digunakan. Pembuatan cookies akan berhasil sesuai dengan kriteria apabila bahan yang digunakan bermutu tinggi, proses pencampuran adonan dan metode pembuatanya benar, serta lama pembakaran dan temperaturnya tepat (Faridah, Pada, Yulastri, \& Yusuf, 2008). Kastangel adalah kue kering yang renyah, adonan mengandung keju, kue ini berbentuk panjang dan memiliki warna kuning keemasan.

Pada penelitian ini ikan bandeng presto dijadikan sebagai tepung kemudian hasil tepung diaplikasikan pada pembuatan Kastangel dengan cara subtitusi bandeng presto. Tujuan dari penelitian ini adalah untuk mengetahui perbedaan kualitas kastangel tepung bandeng presto dengan subtitusi $(0 \%, 10 \%, 20 \%, 30 \%)$ ditinjau dari aspek inderawi yaitu warna, rasa, tekstur, dan aroma. Penelitian ini juga bertujuan untuk mengetahui tingkat kesukaan masyarakat terhadap kastangel hasil eksperimen. Selain itu, penelitian ini juga bertujuan untuk mengetahui kadar protein dan kalsium pada kastangel subtitusi tepung bandeng presto.

\section{METODE}

Jenis penelitian ini berupa eksperimen (adanya perlakuan/treatment). Desain eksperimen menggunakan RAL faktor tunggal. Objek penelitian ini adalah kastangel subtitusi tepung bandeng presto yang berbeda. Terdapat 3 jenis variabel penelitian yaitu variabel bebas, variabel terikat, dan variabel kontrol. Variabel bebas dalam penelitian ini adalah jumlah penggunaan tepung bandeng presto dengan prosentase $0 \%, 10 \%, 20 \%$ dan $30 \%$. Dalam penelitian ini variabel terikatnya adalah kualitas kastangel dilihat dari mutu inderawi dengan indikator warna, rasa, aroma dan tekstur serta kandungan gizi protein dan kalsium. Dalam penelitian ini variabel kontrolnya adalah jenis bahan dan jumlah bahan tambahan yang digunakan proses pembuatan dengan perlakuan yang sama pada pencampuran, pencetakan, dan pemanggangan.

Metode pengumpulan data menggunakan penilaian subjektif yaitu uji inderawi dan uji kesukaan, sedangkan penilaian objektif dengan uji Laboratorium. (1) Uji inderawi, untuk 
mengetahui ada tidaknya perbedaan kualitas tiap sampel kastangel subtitusi tepung bandeng presto pada indikator warna, rasa, aroma, dan tekstur. Uji inderawi yang dilakukan menggunakan panelis agak terlatih Panelis agak terlatih merupakan kelompok dimana anggotanya merupakan hasil seleksi kemudian menjalani latihan secara kontinya dan lolos pada evaluasi kemampuan (Kartika, Hastuti, \& Supartono, 1988). Panelis agak terlatih yang digunakan untuk uji inderawi jumlahnya berkisar antara $8-25$ orang yang dipilih setelah calon panelis mengikuti seleksi panelis dengan berdasarkan ketentuan-ketentuan / persyaratan yang harus dipenuhi yaitu : a) Ada perhatian / minat terhadap pekerjaan ini. b) Dapat menyediakan waktu khusus dan punya kepekaan yang dibutuhkan.

Panelis agak terlatih yang memenuhi syarat tersebut harus mengikuti validasi instrumen dan realibilitas instrumen. Validasi instrumen adalah upaya untuk mendapatkan instrumen yang valid dan sahih. Sedangkan validitas instrumen adalah suatu ukuran yang menunjukan tingkat-tingkat kevalidan atau kesahihan suatu instrumen. Sebuah instrumen akan dikatakan valid apabila mampu mengukur apa yang harusnya diukur dan mampu mengungkap data dari variabel yang diteliti secara tepat (Suharsimi, 2010). Realibilitasi instrumen yaitu suatu eksperimen cukup dapat dipercaya untuk digunakan sebagai alat pengumpul data karena instrumen tersebut sudah baik. Instrumen yang baik tidak akan mengarahkan responden untuk memilih jawaban-jawaban tertentu. Reliabel menunjukan pengertian dapat dipercaya dan dapat diandalkan karena sudah memiliki keajegan atau ketetepan (Suharsimi, 2010). Panelis sebanyak 11 orang dengan 3x pengulangan. (2) Uji kesukaan, untuk mengetahui tingkat kesukaan masyarakat terhadap kastangel subtitusi tepung bandeng presto. Uji kesukaan dilakukan dengan menggunakan panelis tidak terlatih sebanyak 80 orang. (3) Uji kandungan protein dan kalsium dilakukan di Laboratorium Chem-Mix Pratama Yogyakarta.

Metode penelitian Anava digunakan untuk mengetahui perbedaan kualitas kastangel tepung bandeng presto dengan subtitusi ( $0 \%, 10 \%, 20 \%, 30 \%)$ ditinjau dari aspek inderawi yaitu warna, rasa, tekstur, dan aroma dan dilanjutkan uji Tukey apabila ada perbedaan kualitas inderawi pada produk, uji kesukaan menggunakan deskriptif prosentase untuk mengetahui tingkat kesukaan masyarakat, uji Laboratorium untuk mengetahui kandungan gizi protein dan kalsium.

\section{HASIL DAN PEMBAHASAN}

Hasil penelitian membahas hasil analisis data yang disajikan dalam rangka menjawab rumusan permasalahan meliputi hasil analisis perbedaan kualitas kastange/ subtitusi tepung bandeng presto, data tingkat kesukaan masyarakat terdahap kastangel subtitusi tepung bandeng presto, dan data kandungan protein dan kalsium pada kastangel subtitusi tepung bandeng presto. Variasi sampel yang digunakan penelitian ini berjumlah 4 sampel yaitu

sampel K (kastangel kontrol), A (kastangel subtitusi tepung bandeng presto 10\%), B (kastangel subtitusi tepung bandeng presto 20\%), C (kastangel subtitusi tepung bandeng presto $30 \%)$.

\section{Uji Inderawi}

Warna. Berdasarkan hasil penelitian panelis terhadap indikator warna pada kastangel sampel subtitusi tepung bandeng presto sampel $C$ memiliki rerata paling tinggi sebanyak 4,21 . Sedangkan $K$ dengan rerata skor 4,15. Sampel A dengan rerata skor 4,18. Sampel B memiliki rerata paling rendah yaitu 3,94. Warna merupakan sensori pertama yang dapat dilihat langsung oleh panelis. penentuan mutu bahan makanan umumnya bergantung pada warna yang dimilikinya, warna yang tidak menyimpang dari warna yang seharusnya akan memberi kesan penilaian tersendiri oleh panelis (Negara, et al., 2016).

Pada uji organoleptik, warna merupakan sifat produk pangan yang paling menarik perhatian konsumen serta paling cepat pula memberi kesan produk tersebut disukai atau 
tidak. Warna memegang peranan penting dalam menentukan mutu suatu produk. Selain faktor yang menentukan mutu, warna juga mempunyai banyak arti yaitu dapat digunakan sebagai indikator kesegaran atau kematangan, kerusakan, serta baik tidaknya cara pengolahan (Soekarto,1985). Warna merupakan komponen sangat penting untuk menentukan kualitas atau derajat penerimaan suatu bahan pangan (Irmayanti, Hermanto, \& Asyik, 2017).

Bersadasarkan uji inderawi terhadap aspek warna untuk keempat sampel kastangel subtitusi tepung bandeng presto $10 \%, 20 \%, 30 \%$, dan $0 \%$ (sampel kontrol), warna sampel yang memiliki nilai paling tinggi adalah sampel $C(30 \%)$ dengan kriteria warna kuning keemasan, sementara sampel A $(10 \%)$, sampel K $(0 \%)$, sampel B $(20 \%)$ memiliki kriteria kuning kecoklatan. Mengarah pada kriteria warna yang baik atau warna tepung bandeng presto mempengaruhi kualitas warna dari kastangel semakin besar subtitusi tepung bandeng presto semakin memberi warna yang baik yaitu kuning keemasan, Sehingga hasil kastange/ menjadi lebih ke kuning keemasan.

Warna merupakan sensori pertama yang dapat dilihat langsung oleh panelis. penentuan mutu bahan makanan umumnya bergantung pada warna yang dimilikinya, warna yang tidak menyimpang dari warna yang seharusnya akan memberi kesan penilaian tersendiri oleh panelis (Negara, et al., 2016). Pada uji organoleptik, warna merupakan sifat produk pangan yang paling menarik perhatian konsumen serta paling cepat pula memberi kesan produk tersebut disukai atau tidak. Warna memegang peranan penting dalam menentukan mutu suatu produk. Selain faktor yang menentukan mutu, warna juga mempunyai banyak arti yaitu dapat digunakan sebagai indikator kesegaran atau kematangan, kerusakan, serta baik tidaknya cara pengolahan (Soekarto, 1985). Warna merupakan komponen sangat penting untuk menentukan kualitas atau derajat penerimaan suatu bahan pangan (Irmayanti, Hermanto, \& Asyik, 2017). Mengarah pada kriteria warna yang baik atau warna tepung bandeng presto mempengaruhi kualitas warna dari kastangel semakin besar subtitusi tepung bandeng presto semakin memberi warna yang baik yaitu kuning keemasan, sehingga hasil kastangel menjadi lebih ke kuning keemasan.

Rasa. Rasa adalah tingkat kesukaan dari yang diamati dengan indera perasa (Negara, et al., 2016). Rasa pada suatu makanan atau minuman mempunyai peranan penting, sebab dengan rasa maka konsumen dapat mengetahui dan menilai apakah makanan atau minuman tersebut enak atau tidak (Kartika, Hastuti, \& Supartono, 1988). Kastangel pada umumnya adalah gurih dengan dominan rasa keju yang digunakan. Pada penelitian kastangel subtitusi tepung bandeng presto dengan prosentase $0 \%, 10 \%, 20 \%$, dan $30 \%$. Berdasarkan hasil penelitian panelis terhadap indikator Rasa menunjukan bahwa untuk keempat sampel kastangel pada indikator Rasa pada sampel subtitusi tepung bandeng presto sampel A memiliki rerata paling tinggi sebanyak 4,21. Sedangakan B dengan rerata skor 4,12. Sampel $C$ dengan rerata skor 4,06. Sampel $K$ memiliki rerata paling rendah yaitu 3,79.

Berdasarkan uji inderawi aspek rasa Kastangel pada umumnya adalah gurih dengan dominan rasa keju yang digunakan. Pada penelitian kastangel subtitusi tepung bandeng presto dengan prosentase $0 \%, 10 \%, 20 \%$, dan $30 \%$. Berdasarkan hasil pengujian inderawi untuk aspek rasa yang dinilai memiliki rasa gurih dihasilkan pada sampel $A(10 \%)$. Untuk sampel B (20\%), sampel C (30\%) memiliki kriteria cukup gurih dan untuk sampel $\mathrm{K}(0 \%)$ memiliki kriteria agak gurih. Hal ini menunjukan penggunaan tepung bandeng presto mempengaruhi rasa yang dihasilkan pada kastangel. Semakin banyak penggunaan tepung bandeng maka akan mempengaruhi rasa gurih yang semakin menurun pada kastangel. Hal ini dipengaruhi oleh tepung bandeng presto yang rasanya begitu kuat. Berbeda dengan kastangel dengan sampel $\mathrm{K}(0 \%)$ memilki kriteria rasa yang kurang gurih karena tidak menggunakan tepung bandeng presto namun rasa gurih dari sampel $K(0 \%)$ hanya didapatkan dari keju. 
Aroma. Aroma adalah bau yang ditimbulkan oleh rangsangan kimia yang tercium oleh syaraf-syaraf olfaktori yang berada dalam rongga hidung (Negara, et al., 2016). Aroma dapat didefinisikan sebagai sesuatu yang dapat diamati dengan indera pembau. Aroma sukar untuk diukur sehingga biasanya menimbulkan pendapat yang berlainan dalam menilai kualitas aromanya (Kartika, Hastuti, \& Supartono, 1988). Pada penelitian ini kastangel menggunakan subtitusi tepung bandeng presto dengan presentase $0 \%, 10 \%, 20 \%$, dan $30 \%$. Berdasarkan hasil pengujian inderawi untuk aspek aroma yang dinilai memiliki sampel K $(0 \%)$, sampel A $(10 \%)$, sampel B $(20 \%)$, dan sampel C $(30 \%)$ memiliki aroma cukup nyata. $\mathrm{Hal}$ ini terjadi Karena aroma bandeng presto pada kastangel subtitusi tepung bandeng presto memiliki aroma yang sangat khas, sehingga apabila disubtitusikan dalam jumlah banyak maka pengaruh aroma bandeng presto menjadi kurang nyata sebaliknya jika subtitusi semakin sedikit akan memberikan aroma nyata.

Berdasarkan hasil penelitian panelis terhadap indikator Aroma Bandeng Presto menunjukan bahwa sampel subtitusi tepung bandeng presto sampel A memiliki rerata paling tinggi sebanyak 4,12. Sedangakan B dengan rerata skor 4,09. Sampel C dengan rerata skor 4,00. Sampel K memiliki rerata paling rendah yaitu 3,55.Berdasarkan data diatas menunjukan bahwa untuk keempat sampel kastangel pada indikator Rasa pada sampel subtitusi tepung bandeng presto sampel A memiliki rerata paling tinggi sebanyak 4,21 . Sedangakan B dengan rerata skor 4,12. Sampel C dengan rerata skor 4,06. Sampel $\mathrm{K}$ memiliki rerata paling rendah yaitu 3,79 .

Tekstur. Tekstur berupa bentuk yang diamati dengan indera peraba (Negara, et al., 2016). Tekstur merupakan sensasi tekanan yang dapat dirasakan dengan mulut dan dirasakan pada waktu digigit, dikunyah, ditelan ataupun perabaan dengan jari (Kartika, Hastuti, \& Supartono, 1988). Tekstur yang baik dipengaruhi oleh bahan dasar yang digunakan. Tekstur makanan ini juga dapat mempengaruhi minat dari konsumen, jika suatu makanan dari segi bentuk saja tidak bagus maka minat konsumen untuk mengkonsumsi makanan tersebut akan berkurang. Tekstur merupakan parameter yang paling menentukan kualitas kastangel. Berdasarkan hasil penelitian panelis terhadap indikator tekstur Bandeng Presto menunjukan bahwa keempat sampel kastangel pada indikator tekstur pada sampel subtitusi tepung bandeng presto sampel $\mathrm{K}$ memiliki rerata paling tinggi sebanyak 4,00. Sedangakan sampel A dengan rerata skor 3,85. Sampel B dengan rerata skor 3,82. Sampel C memiliki rerata paling rendah yaitu 3,36 .

Berdasarkan hasil pengujian terhadap keempat sampel kastangel subtitusi tepung bandeng presto $0 \%, 10 \%, 20 \%$ dan $30 \%$, sampel yang paling baik menurut panelis yaitu $\mathrm{K}$ $(0 \%)$, sampel A (10\%), sampel B $(20 \%)$ dengan kriteria cukup renyah. Sedangkan sampel C (30\%) memiliki kriteria agak renyah. Hasil keseluruhan dari uji inderawi menunjukan bahwa semakin bertambahnya penggunaan tepung bandeng presto maka tekstur kastangel akan semakin mudah rapuh.

\section{Tingkat Kesukaan}

Hasil analisis data tingkat masyarakat terhadap kastangel subtitusi tepung bandeng presto yang telah dilakukan oleh panelis tidak terlatih menghasilkan total skor yang hampir sama pada keempat sampel kastangel. Dimana secara umum 80 orang panelis tidak terlatih memberikan penilaian cukup suka dan agak suka terhadap kastangel. Walaupun demikian masih terdapat berbedaan pada skor atau total skor penilaian pada kriteria cukup suka yang diperoleh masing-masing sampel $\mathrm{K}$ yaitu $55,75 \%$, sampel A $55,25 \%$, sampel B 52,9\%. Sedangkan untuk kriteria agak suka yang diperoleh sampel C yaitu 49,7\%.

Hasil dari kesukaan warna kastangel yaitu yang disubtitusikan dengan tepung bandeng presto. Hal ini disebabkan karena warna kastangel yang dihasilkan berwarna kuning kecoklatan. Warna kuning kecoklatan timbul dari tepung bandeng presto yang disubtitusikan pada kastangel dan warna dari margarin. Warna kuning kecoklatan salah satunya 
dipengaruhi oleh penggunakan margarin disamping itu subtitusi bandeng presto juga mempengaruhi pada warna karena terdapat kandungan protein yang berpengaruh terhadap terjadinya reaksi maillard yang menghasilkan senyawa berwarna coklat yang disebut melanoidin (Nurbaya \& Estiasih, 2013)

Hasil uji kesukaan rasa kastangel yaitu yang disubtitusikan dengan tepung bandeng presto. Hal ini disebabkan karena rasa yang dihasilkan menjadi gurih. Adapun penambahan bandeng presto dan beberapa bahan juga berpengaruh terhadap rasa cookies, seperti susu skim yang berperan memperbaiki rasa. Hal ini diduga panelis memiliki selera yang berbedabeda mengenai rasa cookies (Nurbaya \& Estiasih, 2013)

Hasil uji kesukaan aroma bandeng presto yaitu subtitusi tepung bandeng presto. Hal ini dikarenakan semakin tinggi subtitusi tepung bandeng presto pada kastangel maka memiliki aroma yang khas ikan bandeng presto. Hal ini disebabkan karena proses pengolahan ikan bandeng presto menggunakan tekanan tinggi sehingga menghasilkan aroma dan rasa spesifik ikan bandeng presto (Falistin, Ma'ruf, \& Dewi, 2015). Bau sering kali menentukan kelezatan bahan makanan. Penilaian terhadap bau dipengaruhi oleh faktor psikis dan fisilogis, sehingga menimbulkan pendapat yang berlainan (Arvianto, Swastawati, \& Wijayanti, 2016)

Hasil uji kesukaan tekstur kastangel yang disubtitusikan dengan tepung bandeng presto yaitu dengan semakin banyak subtitusi tepung bandeng pesto maka nilai kesukaan akan semakin menurun. Sehingga Kastengel tanpa subtitusi tepung bandeng presto memiliki tekstur paling renyah. Hal ini disebabkan tepung terigu sebagai bahan utama pembuatan kastangel. Salah satu yang mempengaruhi Kehalusan tekstur cookies yaitu dengan menggambarkan karakteristik remah cookies dari yang sangat kasar hingga sangat halus. Sehingga lemak menjadi salah satu yang dapat memperbaiki tekstur produk akhir. Hal ini disebabkan karena lemak mempunyai kemampuan memerangkap udara saat proses pencampuran bahan-bahan (mixing) udara akan terperangkap dalam adonan. Penggabungan gelembung-gelembung udara kecil dalam adonan dapat membantu dalam pengembangan dan dalam membangun struktur produk akhir (Nurbaya \& Estiasih, 2013).

Berdasarkan Hasil analisis data tingkat kesukaan masyarakat terhadap kastangel subtitusi tepung bandeng presto yang telah dilakukan oleh panelis tidak terlatih menghasilkan total skor yang berbeda pada keempat sampel kastangel. Dimana secara umum 80 panelis memberikan penilaian cukup suka dan agak suka pada keempat sampel kastangel. Walaupun demikian masih terdapat berbedaan pada skor atau total skor penilaian pada kriteria cukup suka yang diperoleh masing-masing sampel $\mathrm{K}$ yaitu $55,75 \%$, sampel A 55,25\%, sampel B 52,9\%. Sedangkan untuk kriteria agak suka yang diperoleh sampel C yaitu 49,7\%. Berdasarkan hasil uji tingkat kesukaan masyarakat semakin banyak jumlah prosentase subtitusi tepung bandeng presto maka semakin menurun tingkat kesukaan masyarakat.

\section{Kadar Gizi Kalsium dan Protein produk Kastange/ Subtitusi Tepung Bandeng Presto}

Berdasarkan uji kimiawi yang dilakukan oleh Laboratorium Chem-Mix Pratama, Yogyakarta dapat diketahui hasil kadar kalsium pada keempat sampel kastangel subtitusi tepung bandeng presto. Dari hasil tersebut dapat dilihat bahwa sampel $\mathrm{K}$ atau kontrol memilki kadar kalsium yaitu $8,26 \%$, sampel A dengan subtitusi tepung bandeng presto $10 \%$ memiliki kadar kalsium 9,60\%, sampel B dengan subtitusi $20 \%$ juga memiliki kadar kalsium yaitu $11,36 \%$ dan sampel $\mathrm{C}$ dengan subtitusi tepung bandeng presto memiliki kadar kalsium paling tinggi $13,83 \%$. Kandungan protein pada setiap sampel kastangel subtitusi tepung bandeng presto $30 \%$ memiliki kadar protein paling tinggi $5,42 \%$ dibandingkan dengan sampel kastangel subtitusi tepung bandeng presto sampel B dan A yaitu 3,66\% dan 2,33\%. Sedangkan untuk kadar protein paling rendah pada sampel kastangel subtitusi tepung bandeng presto pada sampel K yaitu $0,49 \%$. 
Protein adalah sebagian dari semua sel hidup dan merupakan bagian terbesar tubuh sesudah air. Protein mempunyai fungsi khas yang tidak dapat digantikan oleh zat gizi lain, yaitu membangun serta memelihara sel-sel dan jaringan tubuh (Almatsier, 2010). Kalsium adalah mineral yang sangat penting bagi tubuh manusia. Kalsium paling banyak terdapat dalam jaringan keras, yaitu tulang dan gigi. Di dalam cairan ekstraseluler dan intraseluler kalsium berperan penting dalam mengatur sel dan mengatur pekerjaan hormon-hormon serta faktor pertumbuhan (Suhartini, Zakaria, Pakhri, \& Mustamin, 2018). Meningkatnya kandungan protein dan kalsium pada kastangel sampel $\mathrm{C}$ yang dihasilkan dimungkinkan karena penggunaan tepung bandeng presto yang lebih banyak dibandingkan dengan penggunaan tepung terigu. Berbeda dengan sampel $\mathrm{K}, \mathrm{A}$, dan $\mathrm{B}$ dimana kandungan protein dan kandungan kalsium pada masing-masing lebih sedikit dibandingkan sampel $\mathrm{C}$. Hal ini menunjukan adanya perbedaan kandungan pada protein dan kalsium pada masing-masing kastangel hasil eksperimen.

\section{SIMPULAN DAN SARAN}

Berdasarkan hasil penelitian dan pembahasan, maka dapat ditarik kesimpulan bahwa Ada perbedaan mutu inderawi pada kastangel subtitusi tepung bandeng presto dengan prosentase $0 \%, 10 \%, 20 \%$, dan 30\% ditinjau dari aspek warna, rasa, aroma bandeng presto, dan tekstur. Sampel yang disukai masyarakat adalah sampel kastangel tepung bandeng presto dengan sampel $0 \%, 10 \%$ dan $20 \%$ dengan prosentase $55,75 \%$, 55,25\% dan $52,9 \%$ termasuk kriteria cukup suka. Untuk Sampel kastangel subtitusi tepung bandeng presto 30\% dengan prosentase $49,7 \%$ termasuk dalam kriteria agak suka. Sampel kastangel subtitusi tepung bandeng presto $30 \%$ memiliki rata-rata kandungan kalsium 13,83\% dan kandungan protein $5,42 \%$. Untuk sampel kastangel subtitusi tepung bandeng presto $20 \%$ memiliki ratarata kandungan kalsium $11,36 \%$ dan kandungan protein 3,66\%. Sedangkan, untuk sampel kastangel bandeng presto $10 \%$ memiliki rata-rata kandungan kalsium 9,60\% dan kandungan protein 2,33\%. Dan untuk sampel kastangel subtitusi tepung bandeng presto $0 \%$ memiliki rata-rata kandungan kalsium $8,26 \%$ dan kandungan protein $0,49 \%$. Maka kandungan kalsium dan protein yang tertinggi pada sampel kastangel subtitusi tepung bandeng presto $30 \%$ sedangkan kandungan kalsium dan protein yang terendah terdapat pada sampel kastangel subtitusi tepung bandeng presto $0 \%$ atau sampel kontrol. Produk kastangel subtitusi tepung bandeng presto cukup berkualitas secara inderawi, cukup disukai masyarakat, serta memiliki kandungan protein dan kalsium yang tinggi. Produk ini dapat menjadi jajanan sehat dan kaya kalsium untuk keluarga. Oleh karena itu, penelitian ini menyarankan untuk dilakukan sosialisasi kepada masyarakat mengenai jajanan sehat dan kaya kalsium untuk keluarga sebagai hasil subtitusi tepung bandeng presto.

\section{DAFTAR PUSTAKA}

Anggraeni, A. A., Handayani, T. H. W., \& Palupi, S. (2017). Sensory characteristic of glutenfree popular Indonesian cookies, Advances in Social Science, Education and Humanities Research,. 1st Proceeding of International Conference on Technology and Vocational Teachers (ICTVT 2017), 102, 8-11.

Almatsier, S. (2010). Prinsip Dasar IImu Gizi. Jakarta: Gramedia Pustaka Utama

Arvianto, A. A., Swastawati, F., Wijayanti, I. (2016). Pengaruh fortifikasi tepung daging lele dumbo (Clarias gariepinus) terhadap kandungan asam amino lisin pada biskuit. Jurnal Pengolahan dan Bioteknologi Hasil Perikanan, 5(4), 20-25.

Chakrabarti, T., Poonia, A., \& Chauhan, A. K. (2017). Process optimization of gluten free cookies using cassava flour. International Journal of Food Science and Nutrition, 2 (5), 190-195. 
Faridah, A., Pada, K. S., Yulastri, A., Yusuf, L. (2008). Patiseri Jilid 3. Jakarta: Direktorat Pembinaan Sekolah Menengah Kejuruan, Direktorat Jenderal Manajemen Pendidikan Dasar dan Menengah, Departemen Pendidikan Nasional.

Falistin, N. B., Ma'ruf, W. F., Dewi, E. N. (2015). Pengaruh tahapan pengolahan terhadap kualitas kandungan lemak bandeng (Chanos Chanos Forks) Presto Goreng. Jurnal Pengolahan dan Bioteknologi Hasil Perikanan, 4(2), 93-99.

Irmayanti, W. O., Hermanto, Asyik, N. (2017). Analisis organoleptik dan proksimat biskuit berbahan dasar ubi jalar (Ipomea batatas $L$ ) dan kacang hijau (Phaseolus radiatus $L$ ). Jurnal Sains dan Teknologi Pangan, 2(2), 413-424.

Kartika, B., Hastuti, P., \& Supartono, W. (1988). Pedoman Uji Inderawi Bahan Pangan. Yogyakarta: Pusat Antar Universitas Pangan dan Gizi, Universitas Gajah Mada.

Kurniasih, R. A., Sumardianto, Swastawati, F., \& Rianingsih, L. (2017). Karakteristik kimia, fisik, dan sensori ikan bandeng presto dengan lama pemasakan yang berbeda. Jurnal IImu Pangan dan Hasil Pertanian, 1(2), 13-20.

Negara, J. K., Sio, A. K., Rifkhan, Arifin, M., Oktaviana, A. Y., Wihansah, R. R. S., Yusuf, M. (2016). Aspek mikrobiologis serta sensori (rasa, warna, tekstur, aroma) pada dua bentuk penyajian keju yang berbeda. Jurnal IImu Produksi dan Teknologi Hasil Peternakan, 4(2), 286-290.

Norhidayah, M., Noorlaila, A.,\& Izzati, A. N. F. (2014). Textural and sensorial properties of cookies prepared by partial substitution of wheat flour with unripe banana (Musa $\mathrm{X}$ paradisiaca var. Tanduk and Musa acuminata var. Emas) flour. International Food Research Journal, 21(6), 2133-2139.

Nurbaya, S. R., \& Estiasih, T. (2013). Pemanfaatan talas berdaging umbi kuning (Colocasia esculenta (L.) Schott) dalam pembuatan cookies. Jurnal Pangan dan Agroindustri, 1(1), 46-55.

Olapade, A. A., \& Adeyemo, M. A. (2014). Evaluation of cookies produced from blends of wheat, cassava, and cowpea flour. International Journal of Food Studies, 3, 175-185. DOI: https://doi.org/10.7455/ijfs/3.2.2014.a4.

Santos, M. M. R, Almeida, G. C. R. D, Candido, C. J., Zampieri, D. F., Vargas, N, O. F., Silva, A. F. D., Nascimento, V. A. D., Novello, D., Hiane, P. A. \& Santos, E. F. D. (2018). Characterization and Sensorial Analysis of Diet Cookies Prepared With Different Levels Of Cumbaru Nut. International Journal of Development Research, 8(6), 21136-21140.

Soekarto, S. T. (1985). Penelitian Organoleptik untuk Inderawi Pangan dan Hasil Pertanian. Jakarta: Bharata Karya Aksara.

Suharsimi, A. (2010). Prosedur Penelitian Suatu Pendekatan Praktek. Jakarta: Rineka Cipta.

Suhartini, T., Zakaria, Pakhri, A., \& Mustamin. (2018). Kandungan protein dan kalsium pada biskuit formula tempe dengan penambahan tepung daun kelor (Moringa oleifera). Media Gizi Pangan, 25(1), 64-68.

Wijayanto, D., \& Widowati, L. L. (2012). Analisis keputusan pembelian bandeng duri lunak pada kawasan pusat oleh-oleh Kota Semarang. Jurnal Saintek Perikanan, 7(1), 70-76. 